\title{
Behind the Doors: Perceptions of Reality
}

\author{
ALBERTO NONES
}

\section{Aesthetic and Ethical Perception of Reality}

Following a contribution on the Doors that recently appeared on this journal, ${ }^{1}$ this paper intends to specify which elements of newness were introduced by the band as well as the roots from which they originated. A secondary aim is to throw some more light on the way the Doors differentiated themselves from the hippie and counterculture movements, although they of course shared many of their motives, the foremost of which was a general sense of rupture. Listening to a song like "Break on Through (to the Other Side)" (track 1 of The Doors, Elektra, January 1967) truly gives the sense of a break to the other side, a passage, a change of physical and metaphysical status. The song opened the Doors' first album and was also their first official single, the medium through which the band began the climb to success. In 1967 calls to break to the other side, which may sound harmless if decontextualized today, were growing. They represented an invitation to make one's way into a dizzying freedom, where life energy was seemingly boundless and aimed at something transcendent. The invitation was to go beyond, and this paper tries to explain in what sense.

It was not the Doors, of course, who invented the concept of going beyond the limits, nor, for that matter, the hippies or the exponents of counterculture. In certain contexts, such as the sixties, this timeless temptation has surfaced in a particularly acute form, as if it were a collective contagion, and its transposition in music can be disruptive. The meaning of the name of the group, the Doors, lay here, in the desire for such an opening. Jim Morrison, the group's singer and leader, suggested this name for his band with reference to The Doors of Perception by Aldous Huxley. The idea of the doors in Huxley's essay was inspired by the verses from the English Romantic poet William Blake: "If the doors of perception were cleansed everything would appear to man as it is, infinite." 2

Revisiting the infinite would be impossible for us, but we must at least notice that Huxley's book, almost a manifesto for the approach to life and reality in the sixties, originated from the work of a vanguard of intellectuals not from the sixties but in fact from the previous decade. Published in the mid-1950s, The Doors of Perception expressed a general feeling of distrust for the ideals and enthusiasms that had been and still were particularly vivid in the United States. One such belief was that it was possible to focus on the economy and on technical progress in order to address the problems of the present and pave the way towards a bright future. However, this was not the case. While the development of technological knowledge expanded, new problems had emerged. First and foremost was the threat of nuclear war and, more subtly, consumerism. ${ }^{3}$ In the spectral and yet wildly hedonistic atmosphere of the Cold War, the

${ }^{1}$ Cf. Christopher Crenshaw, "Five To One: Rethinking the Doors and the Sixties Counterculture," Music and Politics 8, no. 1 (2014).

${ }^{2}$ Aldous Huxley, The Doors of Perception - Heaven and Hell (New York: Harper, 1954), quoting “A Memorable Fancy” from William Blake's The Marriage of Heaven and Hell.

${ }^{3}$ See Theodor W. Adorno, Prismen: Kulturkritik und Gesellschaft (Frankfurt am Main: Suhrkamp, 1955). 
parameters of modernization began to be questioned, starting with one of its key foundations: rationalism. The mother of all criticisms bound to conflagrate in the sixties was the critique of the neo-positivist confidence in the ability to know through reason and to find solutions through criteria that claimed to solve exhaustively all the ganglia of a system.

Huxley's book is of particular interest not so much for what it describes (experiments in which the writer himself participates consuming mescaline, the active compound which occurs naturally in peyote) as for the cultural and aesthetic discourse it introduces. According to Huxley, subjects with an exceedingly strong imagination, and in extreme cases such as Blake, true visionaries, have by nature already opened the doors of perception. Achieving that kind of experience for other people, however, would require the consumption of substances. Huxley maintains that the function of these substances is not to produce visions, but to inhibit a faculty of the intellect that prevents us from seeing them in the first place. It is as if the visions were already there and, in fact, the visions are already there, all floating in the miracle of creation, as evidenced by the enchantment of the child before reality. ${ }^{4}$ A child can be captivated by an object because of its beauty, vivid color, the uniqueness of its shape, its feel or consistency, the quality of its odor, an so on, and every object in the world in this view is magical or sacred in its very existence. Under the effect of four-tenths of a gram of mescaline, Huxley recalls his return to this state of astonishment for all that exists, a new Adam in front of the miracle of being.

Huxley's discourse is at once aesthetic and ethical, because man, through a new perception of forms, shapes, and colors comes to the awareness of the gift of his own being in a created world. According to Huxley, the brain and nervous system have mainly an eliminative and not productive function. ${ }^{5}$ As a being that is part of the whole creation, man would have an innate sense of the harmonic beauty and moral perfection of the universe. However, in order to live and move into the world of doing, a world of knowledge to be applied, and especially into the world in which man is to survive, his brain must eliminate, at least in the state of consciousness and wakefulness, a kind of perception that would be of weight, or an unnecessary burden. Language is a perfect example of this, invented as a means of communication and composed of a limited number of symbols and styles that limit behaviors according to its own rules. The brain has to do basically one activity, that is, reducing. Huxley spoke effectively of man's reducing valve, arguing for the need to reopen it. This concept would so strongly impress Morrison and many others along with him in the next years as they sought to reopen the valve, reopen the doors. ${ }^{6}$

Listening to a song of the Doors like "Strange Days" (track 1 of Strange Days, Elektra, October 1967), one realizes that, when the doors of perception have been opened, days do indeed appear to be "strange." Morrison followed Huxley's method rather precisely, that is, he made use of hallucinogenic drugs during

\footnotetext{
${ }^{4}$ Certain aesthetic observations originating from the heart of Europe some sixty years earlier come to mind, for instance by Italian decadent poet Giovanni Pascoli on the fanciullino (little child) who feels and experiences the mystery of the world. According to Pascoli, too, one should get rid of the superimposed social and cultural structures to regain the mysticism of the real, and this occurs via the recovery of the child in us. But for Pascoli, this was the product of a spiritual elevation that was eminently poetic, not induced by the use of substances, which inversely was the case for many other decadent poets (think of Baudelaire's Artificial Paradises).

${ }^{5}$ Huxley's general reference on this is to philosopher Henri Bergson, who he came to through the work of C.D. Broad.

${ }^{6}$ This interpretation of the need to open the doors of perception, initially through the ingestion of drugs, is confirmed in the story recounted by Manzarek, the organist of the band, in Ray Manzarek, Light My Fire - My Life with the Doors (East Rutherford: Putnam, 1998), where the use of psychedelic drugs is presented as functional to a whole new way of seeing reality. Manzarek describes in detail his experiences with both marijuana and the most devastating substance that was then introduced with the name of LSD-25. He also broadens the discussion by noting that the American (and more generally Western) state system typically has incorporated an aversion that has become a prohibition of those substances which-he concluded-only facilitates the process of opening the mind, whereas it legalizes things really destructive, multipliers of violence such as alcohol and guns.
} 
the weeks at Venice Beach when he wrote most of the poetic material from which he was still drawing for the songs of the band's second album. The vision that emerges in Morrison's verses is arcane. His voice is carried in two signals, one altered by reverb and the other simultaneously used to gate an organ (with tremolo) through a vocoder. ${ }^{7}$ This sinister effect evokes images through a mysterious singing, depicting things as if from the outside of any rational perspective and alluding to the reappearance of the incomprehensible charm of existence, ${ }^{8}$ something very similar to what had been theorized by Huxley. Morrison's song gradually grows in a crescendo that climbs up but compresses the energy, stifling it in a grotesque aura. The last stanza is lapidary: "Strange days have found us and through their strange hours we linger alone, bodies confused, memories misused, as we run from the day to a strange night of stone." Huxley had actually already warned that the ingestion of psychedelic substances, while able to promote a feeling or sense of free consciousness in the cosmos, which he claims is our basic existence, may also cause malaise due to the emergence of a distressing sense of panic. The effects of mescaline, Huxley specified, depend on the nature of the subject who makes use of it: a character naturally prone to anger, fear, and anxiety, would likely fall straight into the well of those negative feelings. Towards the end of the essay "Heaven and Hell," Huxley also stated that visionary experience is not the same as mystical experience. Only the latter is truly beyond the realm of opposites, and there was nothing genuinely transcendental in the use of drugs. It could not put man face to face with Truth but could at most help open new perceptions, or at least give the feeling of such experience. The subject remained within this side of reality, and as for the other side, man could only desperately aspire to break through. Indeed, the final effect could be not illumination but a severe blackout.

A recited poem, "Horse Latitudes" (Strange Days, track 5) unveils a gruesome scene: on galleons headed to the new world, stranded in an area around the equator, the sailors try to free the boats by dumping the weight of the horses, which are thrown alive into the sea. ${ }^{9}$ Tragically reeling, the horses drown in the waves and sink to the bottom while the background music of the poem resembles a demonic howl, a whisper of hell. The sea of "Horse Latitudes" is calm yet bleak, a sea where life ends up "in mute nostril agony." Morrison might have meant to suggest that the society in which he had grown up during the fifties was a surreal, dry sea. ${ }^{10}$ And despite of the myth of freedom that characterized the sixties, Morrison believed very little in that dream of collective rebirth. He rather associated this time with a sense of death and a certain sacrifice of dreams and real vitality. Those of Morrison are personal dreams, or

\footnotetext{
${ }^{7} \mathrm{I}$ am indebted to an anonymous reviewer of my paper for this description of what I had thought was simply the filtering through an echo effect.

${ }^{8}$ Morrison's poem "Cock-pit" expresses the same concept: "Reality is what has been / concealed from us / for so long." Jim Morrison, The American Night: The Writings of Fim Morrison, vol. 2 (New York: Vintage Books, 1991), 28.

${ }^{9}$ The image of the galleon appeared on the journey from Africa to the new world in a book by Céline that Morrison was very fond of. See Louis-Ferdinand Céline, Voyage au bout de la nuit (Paris: Denoël \& Steele, 1932).

${ }^{10}$ It should be noted here, however, that in that same society of the fifties Morrison had acquired his culture, forged by a voracious enjoyment of Beat poetry, cinema, literature, and sociology. The critique, therefore, is to be understood as aimed at the drift of the political apparatus and a mass tendency, rather than in absolute terms. Stravinsky lived at that time in West Hollywood whereas, until 1952, Thomas Mann had lived at the Pacific Palisades (the rich neighborhood, where the parents of Robby Krieger, guitarist of the Doors, were soon to move in). A total debt due to the fifties and its culture and, more specifically, its music (from Chicago blues to the formidable appearance of Elvis Presley) can be found in Manzarek, Light My Fire, chapter 3, in which the keyboardist describes learning experiences and artistic apprenticeship in the crucial adolescent period (Manzarek was born in 1939) which are reflected in his friend Jim Morrison (born in 1943). From the Fifties originated, besides the works of Huxley, so central to the very concept of the Doors, theatrical performances of Oedipus Rex, also cited by Manzarek and essential for the Doors in the creation of the their most significant song, "The End." For an interpretation of this song, see chapter 6 of Alberto Nones, Ascoltando i Doors: l'America, l'infinito e le porte della percezione (Milano: Mimesis, 2014).
} 
nightmares, where there is a protagonist with at most one companion at his side. The two retreat from social life into a state of loneliness. This is not a typical theme of the sixties.

In order to perceive, one must first be a subject, and Huxley's essay too had opened with this statement: "We live together, we act on, and react to, one another; but always and in all circumstances we are by ourselves." Both conditions are true, in the sense that our social being, more or less sociable and with a higher or lesser degree of knowledge or consciousness about our dependence on the various communities to which we belong, does not call into question our being alone. The new doors, for Morrison, did not lead to the socialization of a square, but instead to an alley of solitude, a place not illuminated by direct sunlight or, if anything, illuminated by the reflected light of the moon. This is the kind of light that irradiates "Moonlight Drive" (Strange Days, track 6). Such a night ride had been evoked already in the first verses that Morrison sang before Manzarek at Venice Beach, triggering the very idea to create a band. ${ }^{11}$ It was all there from the beginning, then. Morrison's invitation is to a night swim under the moon, or rather to the moon. He invites people to climb on the tide, up, up to the moon. But the movement, one discovers at the end of the song, is downwards: "Gonna get real close, real tight, baby, gonna drown tonight, gonna drown drown drown." It's an invitation to a suicide pact or maybe just to an endless indulgence before the infinite. The key symbol is that strange, strange thing called the moon, which in 1967 was already in the sights but had not yet been touched by the boot of technological man. Before the moon landing, only poetry, in its maiden harmony with the universe, could have "drown" up there or down there, in a reflection on the sea. The image of drowning, which we found in the poem about the horses, reemerges here, and poem and song are connected in the album as they were in the concerts.

With "People Are Strange" (Strange Days, track 7), one may easily switch from a reflection on the fact that these are strange days, which we found in the song "Strange Days," to a consideration of the strangeness of society in general. The piece ends with an arpeggiated, unresolved dominant chord with vibrato bar, which seems to perfectly mirror a question mark. Having opened the doors of perception, Morrison has not found anything exciting or anything explicitly positive. His ride in the moonlight led him to the bottom of the ocean, and everything may have ended there, in underwater silence. But things do not end there. Opening one's eyes, man no longer feels odd. In his abysmal loneliness he has become a stranger, who, from the outside, can better look inside himself and others, into the whole society that surrounds him. "People are strange when you're a stranger," reads the first verse of the song, with a sense of ironic levity. At this point, after stranger Morrison has lifted the eyes of perception, we can look at which kind of social and political America he sees. ${ }^{12}$

\footnotetext{
${ }^{11}$ Manzarek, Light My Fire. To date, the most truthful biographies of Morrison are Jerry Hopkins and Danny Sugerman, No One Here Gets Out Alive (New York: Warner Books, 1980), and James Prochnicky and Jerry Riordan, Break on Through (New York: Morrow, 1991). A pioneering work on the cultural climate around Morrison and the Doors is Wallace Fowlie, Rimbaud and Fim Morrison: the Rebel as Poet (Durham: Duke University Press, 1994), an essay in comparative literature; on the same line but perhaps more open in terms of interpretative range is Francesco Guadalupi, Wake up! I numi tutelari di fim Morrison (Reggello: Firenze Libri, 2010).

${ }^{12}$ In a 1971 interview for Bob Chorush, Morrison states that in the band's first album there was no real social conscience but only generic personal addresses, and only at a later stage their consciousness of everything around took form, album after album. See Jerry Hopkins, The Lizard King: The Essential fim Morrison (London: Plexus, 1992).
} 


\section{Social and Political Perception of Reality}

While the critique of rationalism had been the starting point to open new doors, soon other parameters of modern development would also be subject to critique. The opening of the doors of perception generates a feeling of strangeness with regard to the object and a sense of alienation when considering the subject. The world offers glimpses for how it should be and, therefore, a complaint can be filed against the world as it has been reduced, a complaint that is the essence of the historical moment in which the Doors were living. Counterculture originated in those years in an attempt to form a critical mass-no longer just the avant-garde of society-that transcended institutionalized knowledge and conventional wisdom. ${ }^{13}$

Considering that the American reality that emerged most starkly in the summer of 1968 was marked by the war in Vietnam, if we shift from the discourse on the aesthetic and ethical perception of reality to one on the social and political perception of reality, we naturally arrive at "The Unknown Soldier" (track no. 6 of Waiting For The Sun, Elektra, July 1968). War was the background to Morrison's entire adult life and the musical life of the Doors, which spanned the period of 1965 to 1971. It is natural, therefore, to wonder if those four young men of military age ever went to the battlefield. Presley had respectfully paid tribute to America's model of the good patriot as shown in the photos that portray him wearing the uniform, but that was in the fifties-another context, another war. A decade that carved a deep groove had passed. The Doors' organist did serve in the army, but took it as an opportunity to visit New York City and then obtain some Thai cannabis from overseas, ${ }^{14}$ while the guitarist and drummer escaped the Draft with various excuses. Morrison, the son of a marine who served on an aircraft carrier in the waters of Vietnam, is the paradigmatic case: when the time came for medical examination, precisely when the U.S. army began to bomb heavily in Vietnam, he showed up completely stoned on drugs and was declared unfit. The case is paradigmatic at several levels: first, because it reaffirms the link between doors of perception, opened with the use of drugs, and a radically critical attitude towards reality as it has been reduced by society; second, because that drastic rejection of reality corresponds to the rift with the previous generation, embodied by the social patterns and the political decisions of the adults; third, the comparison between generations is amplified in the case of Morrison, as his father was an emblem of the system that the youth wanted to subvert, a representative of the United States army. These elements conjoined constitute key figures of the revolution of the sixties. ${ }^{15}$ For the first time, at least at this level of confrontation, a generation gap took the fore, in which it was no longer children who feared the judgment of their parents but parents who were judged by their children; they became separate entities and their traditional relationship was altered. ${ }^{16}$ The two categories of persons no longer identified with each other. The young revolutionaries in America took one of two paths: one self-segregated and formed closed communities, pivoting on drugs, the abolition of private property, free love, or even just the looks of long

\footnotetext{
${ }^{13}$ For a discussion of counterculture as a political and sociological phenomenon, and more generally as an attempt to go beyond mainstream culture, see Theodore Roszak, The Making of a Counter Culture: Reflections on the technocratic Society and Its Youthful Opposition (Berkeley: University of California Press, 1969), a fundamental book for understanding the sixties. Far from being exclusive to the twentieth century, however, forms of "counterculture" have often marked historical developments, a decisive moment being, for example, the Sturm und Drang-which was similarly characterized by the concept of the primacy of intuition and a new relationship with nature and with society and its rules-although such movement, indeed, was certainly not destined to be a mass movement.

${ }^{14}$ Admission by Manzarek in Light My Fire.

${ }^{15}$ And they came together in an unsurpassed way the Doors' song "The End." For an interpretation of that song, see Nones, Ascoltando i Doors, chap. 6.

${ }^{16}$ See Ernesto Assante and Gino Castaldo, Il tempo di Woodstock (Bari: Laterza, 2009).
} 
hair and other symbols of freedom, ${ }^{17}$ while the other was more political, centered on campuses (Berkeley in particular), and took the first difficult steps toward effecting a newly imagined, alternative social reality.

With "The Unknown Soldier," the Doors voiced the rising sentiment against one aspect of international politics, a Pax Americana that was in reality always permeated by war. The song was released as the A-side of a single in March 1968 and was subsequently included on Waiting for the Sun. It was a controversial song to play on the radio in those days, when AM stations replayed harmless hit-parade songs while only a very few, including some of the first FM stations, began to introduce audiences to more original and controversial artists. The Doors also tried to enhance "The Unknown Soldier" by shooting a music video. Although the genre was still in its early days, Morrison and Manzarek had previously met in film school and hence had the right experience. The video illustrates the song as a rock monument to the Unknown Soldier but not at the hands of the establishment, as is typical for such monuments, but in a revised version of the counterculture. The result is a depiction of the futility of death in war. At first one sees Morrison walking on the beach with a bunch of flowers; then he is tied to a post and finally shot by a firing squad constituted by the other members of the band; he dies spitting blood on the bouquet. The scene, which overlaps with several other images of life, war, and peace, suggests a crucifixion. Not surprisingly, the song ends with the jubilant cry of "it's all over, the war is over."

It remains to be seen if all this was meant to confirm an optimistic belief in pacifism. Although there were still many who believed in a possible future of peace, love and brotherhood, Morrison in particular developed a mature conviction about the general negativity of the strange days he was living in. ${ }^{18}$ He was right to the extent that the Summer of Love, which was born despite ominous signs, such as the assassination of John F. Kennedy back in 1963, ended with the murders of Martin Luther King, Jr., in April of 1968, and Robert Kennedy, in June of the same year. The new president, Nixon, was an archenemy of the counterculture. And the war in Vietnam, instead of terminating, spread to Laos and Cambodia, while the violence of repression made it to the streets of America (and Europe, where the Prague Spring was crushed by Russian tanks). Violent, reactionary politics were closing the doors on a revolution that had aspired to be nonviolent. The lead singer and leader of the Doors, for one, realized that the revolution had to be very deep to become reality. In an interview, Morrison admitted that he did not know much about politics but, from what he understood, it was necessary that a revolution be permanent, constant, and habitual. ${ }^{19}$ It was necessary to instill the roots of a new mindset deep into the habit and practice of a new way of life.

\footnotetext{
${ }^{17}$ They could be seen as symbols in a rather profound sense. The lack of attachment to objects of personal property, for example, an almost "un-American" attitude, distinguished in a marked and significant way the understanding and practice of freedom on the part of Morrison himself, who showed a somewhat evangelical lack of interest not only in earthly goods, such as houses or cars (and he did earn the means to buy them), but even in personal effects and clothing. See "New Boots" in Frank Lisciandro, An Hour for Magic (New York: Delilah, 1982).

${ }^{18}$ In this Morrison was in good company with other artists of the L.A. scene, such as Frank Zappa and Buffalo Springfield as well as with the sentiments expressed in some of the Beatles' more critical songs such as "Revolution" and "Revolution 9" (written by John Lennon).

${ }^{19}$ Interview with John Tobler of 1970, quoted in Hopkins, The Lizard King. It is interesting to note that Manzarek, in his last book on the Doors, presents the purpose of the band in political terms much less hesitant compared to those chosen by Morrison: he spoke of a revolutionary goal, and also quite political, for a new politics totally different from that of the past, and presented this goal as central to what the Doors had been from the very beginning, to the point that the keyboardist confesses he had already foreseen in Morrison a possible future president. After Reagan and the baptism of politics in the chrism of cinema and pop culture, apparently everything seemed possible to Manzarek. The antagonism between a "fascist" America of capitalist industry and a revolutionary minority fighting for radically new forms of freedom, runs throughout the book of Manzarek and, as he presented it, expressing this antagonism was the entire purpose of the Doors.
} 
Further south, and a little beyond the ideological spectrum tolerated in the United States, Cuban musician Carlos Puebla sang in 1965 "Hasta Siempre, Comandante," dedicated to a political leader who made the need for permanent revolution his personal creed as well as the creed for a whole people. Curious, as much as most likely unintended, how the final chord on the guitar in Puebla's song seems to resound in the final chord of "People Are Strange." Some sort of psychedelic echo. ${ }^{20}$

\section{A Different Idea of America}

The United States originated as an extension to the west, a continuous movement of the frontier westward. The essential point of reference for the vision of the formation of the United States as westward movement of the border is the Turner thesis, ${ }^{21}$ according to which American social and political life was born from the encounter between European civilization and the wilderness. The process of Americanization was a process of colonization, which took form through contact with the "Wild West." This argument also raised the question of what would happen once the United States had reached its western geographical limit. Subsequent elaborations of the thesis, as well as historical development, suggested two directions the country could take: on the one hand, there was the prospect of the United States expanding beyond the limits already reached, ${ }^{22}$ on the other hand, new sensitivities began to take shape and spread, especially in the sixties, resulting in a need to begin the process of rethinking the whole idea of frontier. ${ }^{23}$

The Doors are quite relevant to this discourse on westward expansion. Their West is a land where, after traveling for so long, one no longer sees the sun going down on plains, deserts or mountains, but, for the first time, sinking into the ocean. California is the final stopping point on this westward journey. One cannot go on, and must necessarily slow down, stop, a drastic change of rhythm. ${ }^{24}$ And in this way one can also make that second step-most characteristic of the sixties-that goes in the direction of a radical criticism of the myth of the frontier: the conquest of the West may be one catalyst for looking inside oneself and seeing everything with a sense of perspective. Where America ends, one can understand that it

\footnotetext{
${ }^{20}$ In Manzarek's book, the only occurrence of some significance with regard to a tangency between communism and the Doors is located in a discussion between student factions triggered by a confrontation on film preferences, in which the position of Morrison pretends to follow the patriotic vein of the typical American and not the cosmopolitan, although he is addressed indignantly as communist by the others.

${ }^{21}$ See Frederick J. Turner, The Significance of the Frontier in American History (Ithaca, Cornell University Press, 1956). Presented by the scholar in 1893, the thesis has remained central to understanding the nature and evolution of the United States.

${ }^{22}$ This vision was incarnated by president Theodore Roosevelt, who had explored American wilderness in the first person and wrote about it in his monumental history of the conquest of the West. See Theodore Roosevelt, The Winning of the West (Lincoln: University of Nebraska Press, 1995). Expansionism was in many ways at odds with the old arguments for isolationism (related to elements of the doctrine of another president, James Monroe, at least with regard to relations between the United States and Europe).

${ }^{23}$ At the political level, think of the rhetoric of President Kennedy, which specifically promoted the idea of a New Frontier, in which the uniqueness of America was to be reconfigured at home, with the actualization of civil rights, and abroad, with a new internationalism, and above all in the name of technological progress, symbolized by the race to the moon, won in 1969 but proposed as a target by Kennedy at the beginning of the decade. However, a general observation may indicate the fact that critiques of the alleged involution of the American republic towards inequality within and imperialism outside its borders, are typically combined with a reinterpretation of the concept of the American frontier, a reinterpretation which had been seen among its early intellectuals such as Poe, Thoreau, and Emerson. On this, see Adorno's 1955 essay, "Aldous Huxley and Utopia," in Prismen.

${ }^{24}$ Of course, differentiations exist, though, even inside California, for example, Los Angeles vs. San Francisco. See Manzarek, Light My Fire. In parallel with this differentiation, one could set up a musical comparison, among many other possible comparisons, between the Doors and the Grateful Dead.
} 
is not everything. Morrison, who will sing "The west is the best," confirms this in an interview, speaking of rebellion and freedom as an invitation to the sunset, the night, the sea, the end, a new Wild West. ${ }^{25}$ Manzarek, in his account of the establishment phase of the Doors, tells of when, after the first rehearsal, the four musicians went to the beach. There, Morrison, arousing the concern of the other members of the newly formed band, stated that it was the end of it all. And contrary to what the others feared, he was not implying that he disliked the way they played.

While "The Unknown Soldier" had spoken about the opposition to U.S. foreign policy, particularly the Vietnam War, with "Peace Frog" (track 4 of Morrison Hotel, Elektra, February 1970) the spotlight was on the interior, the bowels of America. Following the repression by the police of the demonstrations that took place in Chicago in October $1969,{ }^{26}$ the text declares, "There's blood in the streets, it's up to my ankles, blood in the streets it's up to my knee." The song calls out city of Chicago: "Blood in the streets of the town of Chicago... Blood on the rise, it's following me." In the middle of the song there are also some verses that are not sung but recited, to which we will return, because they are revealing. For now, let us note that the blood has become a river that flows through the city and overwhelms everything. The blood is following the subject, and we need to understand in what sense.

A disturbing metaphor- "The river runs down the legs of the city"-implies that we are witnessing a kind of birth: "Blood will be born in the birth of a nation." The Latin etymology of the term nationnata, i.e., born or generated-suggests that any nation originates in blood. But the frog in the title "Peace Frog" recalls the frogs of Revelation (16), which symbolize the demons that, at Armageddon, shall gather the kings of the nations in order for the world of man to be judged. In the biblical passage the images of a river and a sea of blood also appear, overflowing the seven bowls of God's wrath. "Peace Frog", with its bizarre title and the strange conjunction between a dramatic text and a funky music, ${ }^{27}$ seems to deliberately expose the contrast between the rhetoric of promise and the reality actualized by America, providing the basis for a radical critique of America by the Doors.

This critique is manifested in the song "L'America" (track 6 of L.A. Woman, Elektra, April 1971). The portrait that this song gives us completely transcends the stereotyped view of America that can be captured by slogans. America remains ultimately indecipherable, just an immense land, where the outcome of freedom, shoved in different directions by millions of hands, is nefarious chaos. Morrison had conceived the song for a film by Italian director Michelangelo Antonioni, Zabriskie Point, which told the story of a student who runs away from the days of rebellion, seeking refuge in Death Valley, where he encounters love and revealing visions about the United States. It makes little difference here that Morrison, when writing the song (which in the end was not part of the film's soundtrack), had Latin America in mind: the reflection is about the lie of America as such, and is a prelude to the unmasking of the deceitful rhetoric of America as the land of freedom.

The song dispels the myth of the American frontier and suggests there must be a problem there from the beginning, from the very fact that all of it had just been an idea, a myth, indeed, rather than a reality. "I took a trip down to America to trade some beads for a pint of gold," read the lyrics. Once again

\footnotetext{
${ }^{25}$ See Hopkins, Lizard King.

${ }^{26}$ See Jeremy Varon, Bringing the War Home. The Weather Underground, the Red Army Faction, and Revolutionary Violence in the Sixties and Seventies (Berkeley: University of California Press, 2004). The climax of the violence was when four students were murdered and thirty others were wounded at Kent State University by the hand of the National Guard. See also Manzarek, Light My Fire.

${ }^{27}$ The euphoric character of the music may be explained by another possible element suggested through the title, that is, the psychotropic power of the poison of certain frogs.
} 
the movement is of descent, "down to America." The title of Antonioni's film also referred to a badland, the point of maximum geological depression in the United States. America appears to be a hole so big that all may fall in it. And the song is sucked down by its slimy riff. Morrison's text avoids a rhyme that nevertheless remains in the ear: the rain man (a metaphor for the man who should arrive to give the solution) "will change your luck. He'll even teach you how to $f$... find yourself." The classic search of fortune and freedom of the American myth reveals itself as a gigantic swindle.

Talking of revelations, we said we would return to a passage of the song "Peace Frog" (1'44"-1'58"), in which Morrison recites the verse: "Indians scattered on dawn's highway, bleeding ghosts crowd the young child's fragile egg-shell mind." Just at that point in the song where an essential criticism was charged against America as born in blood and therefore still dripping blood, Morrison inserts this poetic and conceptual image, linked to a childhood memory. When he was about four years old, he was traveling with his family and they passed by the scene of a car accident involving some Pueblo Indians on a highway between Albuquerque and Santa Fe. When he became a rock star, knowing how to impress the media with flowery phrases, ${ }^{28}$ Morrison declared to the press that the soul of the dying Indians, in that moment, had taken possession of him. Oliver Stone in his film on the Doors seems to take this statement literally, but Morrison was literary, never literal. If the episode had been stuck in his mind, it matured symbolically-in this, and no other sense, was Morrison a "shaman." 29 In the vision of the Indian blood spread on the road in the triumphant march of an American family traveling west, to the future, Morrison identified for the first time a symbolic representation of a betrayal: America had spread a myth of openness and freedom, but was been built on the negation of someone else's freedom. The displacement of the Native Americans was one of America's original sins; another was slave-trade. These two elements define the dark side of the westward movement of the frontier. In a sense, American freedom was not so much the freedom of the pioneers, but the freedom of those who had lived freely before Americans' plans interfered with them. America found room for freedom in annihilating the freedom of others, segregating them or driving them westward to the point, recalling another metaphor by Morrison that we have seen, of throwing them like living horses into the sea. The description of the episode of the accident can also be found in the testimony by Morrison's grandmother: "There were Indians who cried and complained. Later we thought it was very unusual, because we believed that the Indians did not weep." ${ }^{30}$ In the spontaneous surprise in the face of the weeping Indians on the part of a classic American family of the 1950s, one can see the plague of impermeability of a certain America, fed with fictions and closures. It was not that the spirit of the Indians possessed Morrison as a child on that highway in the West; rather, a sensitivity was born in him for the hidden pain that permeates the history of America and the American way of life.

\section{Conclusion}

Trying to throw some light on the "darkness" of the Doors in relation to other rock bands of the time, this paper has argued that it was a critical sensitivity about the hidden pain that permeates the history of America and the American way of life which specifically distinguished the Doors from the hippie culture of San Francisco. ${ }^{31}$ Such sensitivity put them at odds with movements that because of their naivety, could not but seem to Jim Morrison as yet another expression of middle class values.

${ }^{28}$ See in this regard the admission in the 1969 interview of Jerry Hopkins reported in Hopkins, Lizard King.

${ }^{29}$ For this argument, see $₫ 3$ of Nones, Ascoltando i Doors.

${ }^{30}$ See Hopkins, Lizard King.

${ }^{31}$ See Crenshaw, "Five To One: Rethinking the Doors and the Sixties Counterculture." 
In any case, why should one sing all this? Why put that sensitivity into music? The relationships between music and society are extremely complex. They are complex and multifaceted because music permeates society in an intricate way that must be deciphered from its context. ${ }^{32}$ To simplify, one could explain the relationship between music and politics with reference to two extreme positions (and most musical instances fall on the continuum between them). On one hand, music can be influenced by politics to the point that music may become one of politics' ideological components. On the other hand, music can influence politics to the point that music no longer simply adorns the world but critically affects it. In other words, on the one hand, music follows the world, representing by sounds contents that are already present in life; on the other hand, music precedes the world, anticipating reality by sounds.

The revolution that took shape in the 1960s had, with a few exceptions, no clear plan to win through an organized force. It had no clear vision of replacing one government with another. It wanted to inaugurate a new perception of the world, with the ultimate goal of, at most, planting seeds that bear cultural fruit over time. The peak of the revolution in the sixties roughly corresponded to the meeting of half a million young people at Woodstock in August of 1969, when the new generation gathered together in freedom and in new approaches to life-before dispersing. ${ }^{33}$ Whether music had been defused by the trade system of rock festivals and record companies or instead had perfected its status as a merely artistic expression that could not serve a political goal (and here there is ample room for critical evaluation), the fact is that the revolution discharged like a lightning through the shock of Jimi Hendrix's electric guitar, and then disappeared. Rock music, which should or could have been just the fuel of a social and political beginning, turned out to be all there was, and the revolution seemed to amount to little more than a blaze of sound.

Morrison had grasped this possible short circuit very well: had the new leaders become the young rock musicians, then the revolution itself, rather than being political and general, would have only been musical and pertinent to the youth only. The Doors did not play at Woodstock because Morrison, who surely knew how to flirt with the masses, did not want to identify with that kind of new collective body, the mass of rock festivals (perfectly absorbed by the system of power, as we see today). This was the point in which the Doors distinguished themselves not just from the hippies but also from the more ideological branches of any counterculture. The Doors' music-their best song-would feature heavily in Francis Ford Coppola's Apocalypse Now, at the heart of an interpretation of the "darkest" side of war and of man. Their criticism went disquietingly beyond the consonance with a 1960s chorus that was becoming a new conformism, which was too self-referential or colluded too much with political and economic aspects of the same mainstream that those masses thought they were challenging. On the contrary, Morrison conceived of the Doors at a level which was distant both from hedonistic music and from the music of a new (false?) consciousness.

\footnotetext{
${ }^{32}$ On the idea of deciphering music from context, see Theodor W. Adorno, Einleitung in die Musiksoziologie: Zwölf theoretische Vorlesungen (Frankfurt am Main: Suhrkamp, 1962).

${ }^{33}$ See Assante and Castaldo, Il tempo di Woodstock. About Woodstock, Morrison told interviewer John Tobler that it gave him the impression of a mass of young parasites fed with a spoon for three or four days. See Hopkins, Lizard King. But fed what? This is an interesting question because Morrison meant to be ironic and slightly superior, whereas the real food of that meeting was precisely, besides ideology, music. This is no contradiction, insofar as Morrison was not at all convinced that music was the artistic form of expression he should have followed in the first place: cinema and poetry had been at the center for him. See Nones, Ascoltando $i$ Doors, chap. 4 and 5.
} 


\title{
Bibliography
}

Adorno, Theodor W. Prismen. Kulturkritik und Gesellschaft. Frankfurt am Main: Suhrkamp, 1955.

__. Einleitung in die Musiksoziologie: Zwölf theoretische Vorlesungen. Frankfurt am Main: Suhrkamp, 1962.

Assante, Ernesto, and Gino Castaldo. Il tempo di Woodstock. Bari: Laterza, 2009.

Céline, Louis-Ferdinand. Voyage au bout de la nuit. Paris: Denoël \& Steele, 1932.

Crenshaw, Christopher. "Five To One: Rethinking the Doors and the Sixties Counterculture," Music and Politics, 8, no. 1 (2014).

Fowlie, Wallace. Rimbaud and Jim Morrison: the Rebel as Poet. Durham: Duke University Press, 1994.

Guadalupi, Francesco. Wake up! I numi tutelari di Jim Morrison. Reggello: Firenze Libri, 2010.

Hopkins, Jerry. The Lizard King: The Essential Jim Morrison. London: Plexus, 1992.

Hopkins, Jerry, and Danny Sugerman. No One Here Gets Out Alive. New York: Warner Books, 1980.

Huxley, Aldous. The Doors of Perception - Heaven and Hell. New York: Harper, 1954.

Lisciandro, Frank. An Hour for Magic. New York: Delilah, 1982.

Manzarek, Ray. Light My Fire: My Life with the Doors. East Rutherford: Putnam, 1998.

Morrison, Jim. The American Night: The Writings OfJim Morrison. Vol. 2. New York: Vintage Books Edition, 1991.

Nones, Alberto. Ascoltando i Doors: l'America, l'infinito e le porte della percezione. Milano: Mimesis, 2014.

Prochnicky, Jerry, and James Riordan. Break on Through. New York: Morrow, 1991.

Roosevelt, Theodore. The Winning of the West. Lincoln: University of Nebraska Press, 1995.

Roszak, Theodore. The Making of a Counter Culture: Reflections on the Technocratic Society and Its Youthful Opposition. Berkeley: University of California Press, 1969.

Turner, Frederick J. The Significance of the Frontier in American History. Ithaca: Cornell University Press, 1956.

Varon, Jeremy. Bringing the War Home: The Weather Underground, the Red Army Faction, and Revolutionary Violence in the Sixties and Seventies. Berkeley: University of California Press, 2004.

\begin{abstract}
If it is hyperbolic to claim that the Doors started a whole new discourse on dimensions so important and allencompassing as aesthetics, ethics, society, and politics, it is nonetheless sensible to discuss whether the band threw the seeds for a profound renewal of all four areas. It of course accomplished this, if at all, along with other active cultural forces of their time, but revealing some independence, the scope of which is also discussed in a paper divided into three sections. The first examines the aesthetic and ethical perception of reality that lies at the origin of the approach of the Doors; the second elaborates on the social and political perception of reality that emerges from their music; the third deals with the more general question of what idea of America takes form through those new doors of perception. In discussing these issues, the paper intends not only to investigate the question of the social function performed by the music of a band in California from 1965-71, but also to reflect on its sense today, when the revolution of the sixties is past history, but the need to reopen the meanings of politics and society remains as lively as ever, in the West as in the rest of the world.
\end{abstract}

